\title{
PENGARUH PELATIHAN LESSON STUDY TERHADAP KOMPETENSI PROFESIONAL GURU DI SEKOLAH DASAR
}

\author{
Elke Maisyarah', Fetri Yeni J² \\ Universitas Negeri Padang, Sumatera Barat, Indonesia ${ }^{1,2}$, \\ Email : Elkemaisyarah@ gmail.com ${ }^{1}$ fetri53829@ yahoo.co.id ${ }^{2}$
}

\begin{abstract}
Abstrak
Rendahnya kualitas pendidikan tercermin dari rendahnya kualitas sumber daya manusia yang disebabkan oleh kurangnya perhatian guru terhadap kualitas proses pembelajaran. Oleh karena itu, peningkatan kualitas pendidikan harus dimulai dengan peningkatan dalam proses pembelajaran. Paradigma yang selama ini hanya mementingkan hasil tes atau ujian harus segera diubah menjadi penekanan pada proses pembelajaran, sedangkan hasil ujian atau ujian adalah dampak dari proses pembelajaran yang benar dan berkualitas. Jenis penelitian ini adalah kualitatif dengan total 12 guru di Kecamatan Kabung, Kota Padang. Indikator yang digunakan dalam perencanaan pembelajaran adalah: 1) kelengkapan file perangkat pembelajaran, 2) Kualitas Rencana Program Pembelajaran (RPP), 3) Inovasi dalam merancang pembelajaran, dan 4) Kesiapan untuk melaksanakan pembelajaran. Kemudian indikator pelaksanaannya adalah 1) Menerapkan pembelajaran sesuai dengan rencana pelajaran yang direncanakan, 2) Menguasai kelas, dan 3) Menguasai proses pembelajaran. Teknik pengumpulan data yang digunakan adalah observasi, dan wawancara. Hasil pelatihan lesson study memiliki efek positif pada kompetensi profesional guru di Cluster 2, Kabupaten Kabung, Kota Padang, dalam hal persiapan rencana pelajaran dan pelaksanaan pembelajaran di kelas.
\end{abstract}

Kata kunci: Pelatihan, Lesson Study, Kompetensi

\begin{abstract}
Abstrack
The low quality of education is reflected in the low quality of human resources caused by the lack of teacher attention to the quality of the learning process. Therefore, improving the quality of education must begin with an improvement in the learning process. The paradigm so far only concerned with the results of tests or examinations must be immediately changed into an emphasis on the learning process, while the results of exams or tests are the impact of the correct and quality learning process. This type of research is qualitative with a total of 12 teachers in Kabung Subdistrict, Padang City. The indicators used in learning planning are: 1) completeness of the learning device file, 2) Quality of the Learning Program Plan (RPP), 3) Innovation in designing learning, and 4) Readiness to carry out learning. Then the implementation indicators are 1) Implementing learning according to the planned lesson plans, 2) Mastering the class, and 3) Mastering the learning process. Data collection techniques used were observation, and interviews. The results of the lesson study training had a positive effect on the professional competence of teachers in Cluster 2, Kabung District, Padang City, in terms of the preparation of lesson plans and implementation of learning in the classroom.
\end{abstract}

Keywords: Training, Lesson Study, Competence

@ Jurnal Basicedu Prodi PGSD FIP UPTT 2019

$\triangle$ Corresponding author :

Address :

ISSN 2580-3735 (Media Cetak)

Email : ISSN 2580-1147 (Media Online)

Phone 


\section{PENDAHULUAN}

Pada akhirnya perkembangan aspek-aspek pribadi seperti sikap, nilai-nilai dan kepercayaan diri siwa dapat berkembang (Slameto, 2010:97). Salah satu diantaranya adalah belajar dengan pengalaman guru lain. Sekolah Dasar di Kecamatan Bungus Kota Padang adalah sekolahsekolah sasaran yang harus dikembangkan menjadi sekolah yang tidak tertinggal dari sekolah lain yang ada di Kota Padang. Permasalahan guru SD di Kecamatan Bungus Kota padang adalah terkait dengan kompetensi guru adalah masih lemahnya kemampuan dalam mengembangkan perangkat pembelajaran. Seperti menyusun silabus, RPP, dll.

Rendahnya mutu pendidikan yang tercermin pada rendahnya mutu SDM disebabkan oleh kurangnya perhatian guru terhadap kualitas proses pembelajaran. Umumnya pembelajaran yang berlangsung di kelas dalam bentuk komunikasi satu arah, guru lebih banyak berceramah dan siswa mendengarkan. Guru beranggapan bahwa tugasnya hanya mentransfer pengetahuan yang dimilikinya kepada siswa dengan target tersampaikannya topik-topik yang tertuang dalam kurikulum kepada siswa. Guru pada umumnya kurang memberi inspirasi kepada siswa untuk berkreasi, berargumen secara ilmiah, dan tidak membimbing para siswanya untuk menuju hidup mandiri. Pembelajaran yang disajikan guru kurang menantang siswa untuk mengembangkan kemampuan dan keterampilan berpikir. Oleh karena itu, perbaikan mutu pendidikan harus diawali dengan perbaikan proses pembelajaran. Paradigma yang hanya mementingkan hasil tes atau ujian harus segera diubah menjadi penekanan pada proses pembelajaran, sedangkan hasil ujian atau tes merupakan dampak dari proses pembelajaran yang benar dan berkualitas.
Agar seorang guru menjadi profesional, guru harus memiliki kompetensi pedagogi, kompetensi profesional, kompetensi kepribadian, dan kompetensi sosial. Kompetesni pedagogi merupakan kemampuan mengelola pembelajaran, Kompentsi profesional, yaitu kemampuan menguasai materi pembelajaran secara luas dan mendalam yang memungkinkannya membimbing peserta didik memenuhi standar kompetensi. Kompetensi kepribadian, yaitu memiliki kepribadian yang mantap, stabil, dewasa, dan berwibawa menjadi teladan bagi peserta didik dan berakhlak mulia. Kopetensi sosial, yaitu kemampuan berkomunikasi secara efektif denga peserta didik, sesama pendidik, dan masyarakat sekitar. Lesson study merupakan salah strategi yang dipandang efektif untuk meningkatkan mutu guru. Lesson study merupakan model lebih berfokus pada upaya pemberdayaan guru sesuai dengan kapasitas serta permasalahan yang dihadapi oleh masing-masing guru. Sehubungan dengan hal itu, maka artikel ini akan membahas apa, mengapa, dan bagaimana lesson study. Lesson study adalah model potensial untuk meningkatkan profesional guru. Guru yang profesional dituntut mempunyai kemampuan menyusun program pengajaran dan mengiplementasikan program pembelajaran tersebut dengan berbagai strategi pembelajaran yang inovatif. Melalui lesson study guru melakukan pengkajian pembelajaran secara kolaboratif dan berkelanjutan berlandaskan prinsip-prinsip kesejawatan dan mutual learning untuk membangun learning community. Kegiatan lesson study yang dilaksanakan secara terus menerus dan berkesinambungan memberikan manfaat yang banyak bagi para guru dan peserta didik. Salah satu manfaatnya adalah peningkatan kualitas guru dalam menyusun perangkat pembelajaran. 
1095 Pengaruh pelatihan lesson study terhadap kompetensi profesional guru di sekolah dasar - Elke Maisyarah, Fetri Yeni J

Lesson study diharapkan dapat dimanfaatkan semaksimal mungkin dalam kegiatan Kelompok Kerja Guru (KKG) sebagai upaya untuk menemukan proses pembelajaran yang dinilai paling efektif dan efisien untuk meningkatkan kualitas proses pembelajaran, yang pada gilirannya dapat berdampak, baik secara langsung maupun tidak langsung untuk meningkatkan hasil belajar siswa. Permasalahan yang dihadapi saat ini adalah sampai seberapa jauh pelaksanaan lesson study dapat diterapkan dalam pembelajaran guru di kelas, bagaimana peran kepala sekolah dan kepala dinas pendidikan dalam pelaksanaan program lesson study, dan bagaimana dampak dari pelaksanaan program lesson study.

Belajar pengalaman guru lain dapat dilaksanakan melalui lesson study. Lesson study merupakan salah satu model pembinaan profesi pendidik melalui pengkajian pembelajaran secara kolaboratif dan berkelanjutan berlandaskan pada prinsip-prinsip kolegalitas dan mutual learning untuk membangun komunitas belajar (Mulyana, 2007). Lesson study merupakan kegiatan yang dapat mendorong terbentuknya sebuah komunitas belajar (learning society) yang secara konsisten dan sistematis melakukan perbaikan diri, baik pada tataran individual maupun manajerial.

Fitur inti dari lesson study adalah pengamatan langsung pelajaran di kelas oleh sekelompok guru yang mengumpulkan data tentang mengajar dan belajar kemudian secara kolektif menganalisanya. Hal ini bertujuan untuk meningkatkan pelajaran mereka dalam beberapa hal dan merencanakan pelajaran penelitian bersama. Salah satu dari mereka kemudian mengajarkan pelajaran, sementara yang lain mengamati, membuat catatan, dan mengumpulkan data di Internet. Kemudian guru bertemu dan menganalisis data yang telah mereka kumpulkan bersama (Vermunt, Vrikki, van Halem, Warwick, \& Mercer, 2019).
Dalam sebuah studi pelajaran dilaksanakan di Indonesia terhadap guru Matematika dan sains menunjukkan perubahan yang dapat diamati dalam kaitannya dengan basis akademik pelajaran, struktur pelajaran, serta reaksi peserta didik ketika diimplementasikan. Dua hal penting dari hasil penelitiannya adalah: 1) kebutuhan untuk mengalihkan fokus dari metode pengajaran ke pembelajaran peserta didik, dan 2) perlu melibatkan seluruh sekolah agar pelajaran pelajaran dapat dilakukan berhasil (Saito, Harun, Kuboki, \& Tachibana, 2006).

Penelitian yang dilakukan oleh Rizki (2017) menyatakan bahwa lesson study sangat baik untuk diterapkan sehingga proses pembelajaran menjadi lebih baik. Lesson study mengajarkan untuk lebih merancang pembelajaran secara terstruktur, meningkatkan kreativitas dan inovasi dalam merancang pembelajaran, serta menjadikan seorang guru memiliki kompetensi yang baik. Vermunt et al. (2019) menyatakan mayoritas penelitian bahwa manfaat positif dari lesson study adalah adanya kolaborasi guru dan pengembangannya dari komunitas pembelajaran yang profesional, pengembangan profesional pengetahuan, praktik dan profesionalisme, fokus yang lebih eksplisit pada pembelajaran peserta didik, dan peningkatan kualitas pengajaran di kelas.

Sebuah studi yang dilakukan oleh Warwick, Vrikki, Vermunt, Mercer, \& van Halem (2016) menunjukkan bahwa guru di tim lesson study dapat memperluas pengetahuan konten matematika mereka, menjadi lebih mahir dalam memunculkan dan menganalisis pemikiran peserta didik, menjadi lebih ingin tahu tentang matematika dan tentang pemikiran peserta didik, ditekankan pemecahan masalah mandiri peserta didik, dan semakin banyak digunakan beberapa representasi untuk menyelesaikan masalah matematika. Selanjutnya yang melibatkan guru sains Singapura 
1096 Pengaruh pelatihan lesson study terhadap kompetensi profesional guru di sekolah dasar - Elke Maisyarah, Fetri Yeni J

yang dilakukan oleh Tan \& Nashon (2013) menemukan bukti pembelajaran guru melalui lesson study terjadi peningkatan derajat pedagogi yang berpusat pada peserta didik, peningkatan kesadaran tentang kemungkinan dan keterbatasan kepercayaan mereka tentang sains pedagogi, dan munculnya pemahaman baru tentang konten kurikulum baru dan pedagogi sains. Penelitian yang dilakukan oleh Soto Gómez et al.( 2015) menyatakan bahwa lesson study menemukan kepercayaan tersirat, kebiasaan, sikap dan emosi yang mendasari praktik, dan eksperimen dari teori baru untuk membentuk kebiasaan baru, keyakinan, sikap dan emosi yang mendukung pengembangan bentuk pengajaran baru. Lebih lanjut penelitian yang dilakukan oleh Samaranayake et al.(2018) menyatakan bahwa lesson study adalah pengembangan profesional yang berharga dan membawa perubahan guru yang signifikan serta memiliki dampak positif terhadap belajar peserta didik.Verhoef \& Tall (2011 mengungkapkan bahwa Lesson Study hasil pengembangan profesional guru digunakan untuk menyempurnakan instrumen observasi Lesson Study.Temuan Vermunt et al. (2019) menunjukkan efek positif dari Lesson Study pada pembelajaran guru yang berorientasi pada makna dan aplikasi serta efek negatif pada pembelajaran yang bermasalah. Anggara \& Chotimah (2012) menungkapkan bahwa penerapan lesson study berbasis MGMP berdampak positif terhadap peningkatan kompetensi profesional guru PKn SMP se-kabupaten Ogan Ilir. Selanjutnya Rozak \& Fauziah (2013) mengungkapkan bahwa lesson study berdampak positif terhadap kompetensi pedagogik guru.

Tujuan pelaksanaan penelitian ini untuk mendeskripsikan pengaruh pelatihan study lesson dalam upaya meningkatkan kompetensi profesional guru dalam melaksanakan pembelajaran di SD

\section{METODE}

Jenis penelitian adalah kualitatif dengan jumlah guru sebanyak 12 orang di Kecamatan Kabung Kota padang. Indikator yang digunakan dalam perencanaan pembelajaran adalah: 1) kelengkapan berkas perangkat pembelajaran, 2) Kualitas Rencana Program Pembelajaran (RPP), 3) Inovasi dalam merancang pembelajaran,dan 4) Kesiapan melaksanakan pembelajaran. Kemudian indikator pelaksanaannya yaitu 1) Menerapkan pembelajaran sesuai RPP yang sudah direncanakan, 2) Menguasai kelas, dan 3) Menguasai proses pembelajaran. Teknik pengumpulan data yang digunakan adalah observasi, dan wawancara.

Rancangan penelitiannya yaitu memilih sekolah yang akan dijadikan lokasi penelitian, kemudian menempatkan guru ke masing-masing sekolah. Selanjutnya guru membuat RPP dan pelaksanaan sebanyak 4 kali dengan masingmasing 2 kali secara konvensional dan 2 kali melalui lesson study. Pada tahap lesson study guru mengikuti langkah-langkah dalam lesson study yaitu ada tahap 1) Plan yaitu guru membuat RPP kemudian didiskusikan oleh beberapa guru dan teman sejawat, 2) Do yaitu melaksanakan proses pembelajaran, dan 3) See yaitu merefleksi proses pembelajaran dan kemudian untuk diperbaiki pada proses pembelajarn selanjutnya. Sedangkan yang tidak menggunakan lesson study, calon guru hanya melakukan perencanaan sendiri yang kemudian dikoresi oleh 1 guru dan proses pembelajarannya hanya diamati oleh 1 guru lain

\section{HASIL DAN PEMBAHASAN}

Lesson study yang merupakan sebuah kerja kolaboratif antara guru diharapkan memberi sumbangan yang besar terhadap peningkatan mutu pendidikan dalam hal ini peningkatan mutu profesional guru. Dengan demikian manfaat dari pelaksanaan Lesson study tersebut dapat dijadikan 
1097 Pengaruh pelatihan lesson study terhadap kompetensi profesional guru di sekolah dasar - Elke Maisyarah, Fetri Yeni J

acuan dalam peningkatan profesionalisme guru.

dengan menggunakan lesson study dan Hasil perencanaan dan pelaksnaan pembelajaran konvensional disajikan pada Tabel 1 berikut ini:

Tabel 1 Hasil perencanaan dan Pelaksanaan Pembalajaran sKonvensional dan Lesson Study

\begin{tabular}{|c|c|c|c|c|c|}
\hline \multirow{2}{*}{ No } & \multirow{2}{*}{ Nama Guru } & \multicolumn{2}{|c|}{$\begin{array}{c}\text { Perencanaan } \\
\text { (Membuat RPP) }\end{array}$} & \multicolumn{2}{c|}{ Pelaksanaan } \\
\cline { 3 - 6 } & & Konvensional & Lesson Study & Konvensional & Lesson study \\
\hline 1 & JR & 76 & 89 & 80 & 89 \\
\hline 2 & KL & 87 & 89 & 84 & 96 \\
\hline 3 & OP & 76 & 86 & 78 & 94 \\
\hline 4 & IH & 79 & 86 & 85 & 96 \\
\hline 5 & OL & 78 & 90 & 77 & 98 \\
\hline 6 & PE & 77 & 94 & 79 & 89 \\
\hline 7 & TR & 78 & 89 & 84 & 89 \\
\hline 8 & UU & 87 & 94 & 90 & 94 \\
\hline 9 & GD & 78 & 78 & 87 & 98 \\
\hline 10 & YT & 76 & 88 & 89 & 96 \\
\hline 11 & RG & 78 & 98 & 90 & 98 \\
\hline 12 & II & 88 & 90 & 91 & 95 \\
\hline
\end{tabular}

Berdasarkan Tabel 1 dapat dilihat bahwa perencanaan dan pelaksanaan pembelajaran berbasis lesson study lebih baik dibandingan yang konvensional. Hasil tersebut merupakan data hasil konversi dari hasil observasi. Kemudian efek lesson study sendiri terhadap peningkatan kompetensi pedagogik guru sangat positif, dimana dengan menerapkan perencanaan dan pembelajaran berbasis lesson study, guru lebih siap dalam memenuhi standar kompetensi pedagogiknya. Semua indikator yang diamati baik pada saat perencanaan maupun pelaksanaan, yang berbasis lesson study jauh lebih baik.Dari hasil observasi diperoleh informasi bahwa pada tahap perencanaan, baik berbasis konvensional maupun lesson study semuanya memenuhi indikator yang pertama, yaitu kelengkapan berkas perangkat pembelajaran. Indikator kedua yaitu kualitas RPP, dimana kualitas RPP yang berbasis lesson study memiliki kualitas yang jauh lebih baik karena pada saat plan prosesnya dibahas bersama-sama oleh ahli, guru, maupun teman sejawat, sehingga banyak saran dan ide yang membangun. Hal itu mungkin tidak didapatkan pada perencanaan berbasis konvensional karena pengerjaannya pun sendiri dan saran hanya dari guru yang komentarnya pun hanya sebatas teknis.

Penelitian ini sejalan dengan penelitian yang dilakukan oleh Sukirman(2010) mengungkapkan bahwa lesson study bermanfaat terhadap pembelajaran di sekolah yaitu untuk mengurangi keterasingan guru dalam perencanaan pembelajaran; membantu guru dengan mengobservasi dalam pembelajarannya; memperdalam pemahaman tentang materi pembelajaran; membantu supaya lebih fokus pada aktivitas belajar siswa; meningkatkan kolaborasi antar sesama guru; meningkatkan mutu guru dan mutu pembelajaran; memberi kesempatan pada guru untuk memberi makna ide-ide pendidikan pada praktek pembelajarannya; mempermudah dalam berkonsultasi dengan pakar dalam hal pembelajaran atau kesulitan materi pelajaran; dan memperbaiki praktek pembelajaran di kelas. Selanjutnya penelitian yang dilakukan Vermunt et al. (2019) menyatakan mayoritas penelitian bahwa manfaat positif dari lesson study adalah adanya kolaborasi guru dan pengembangannya dari komunitas pembelajaran yang profesional, pengembangan profesional pengetahuan, praktik 
dan profesionalisme, fokus yang lebih eksplisit pada pembelajaran peserta didik, dan peningkatan kualitas pengajaran di kelas. Lebih lanjut studi yang dilakukan oleh Warwick, Vrikki, Vermunt, Mercer, \& van Halem (2016)menunjukkan bahwa guru di tim lesson study dapat memperluas pengetahuan konten matematika mereka, menjadi lebih mahir dalam memunculkan dan menganalisis pemikiran peserta didik, menjadi lebih ingin tahu tentang matematika dan tentang pemikiran peserta didik, ditekankan pemecahan masalah mandiri peserta didik, dan semakin banyak digunakan beberapa representasi untuk menyelesaikan masalah matematika. Di sebuah studi yang melibatkan guru sains Singapura, (Tan \& Nashon, 2013) menemukan bukti pembelajaran guru melalui lesson study terjadi peningkatan derajat pedagogi yang berpusat pada peserta didik, peningkatan kesadaran tentang kemungkinan dan keterbatasan kepercayaan mereka tentang sains pedagogi, dan munculnya pemahaman baru tentang konten kurikulum baru dan pedagogi sains. Berdasarkan uraian di atas dapat disimpulkan bahwa manfaat dari lesson study adalah: (1) menciptakan suasana keakraban dan kekeluargaan antar sesama guru. (2) memberi peluang bagi guru untuk memecahkan berbagai masalah dan menciptakan solusinya secara bersama-sama serta saling bertukar pengalaman. (3) memberikan kesempatan bagi guru untuk dapat membuat perencanaan pembelajaran secara bersama-sama dan mempraktekan hasil kerjanya. (4) membuat guru menjadi lebih profesional dalam mengajar sehingga menciptakan suasana belajar yang kondusif bagi peserta didik sebagai tujuan menelurkan para peserta didik yang terbaik demi masa depan Indonesia.

\section{SIMPULAN}

Pelatihan lesson study memberikan pengaruh yang positif terhadap kompetensi profesional guru di
Gugus 2 Kecamatan Kabung Kota Padang yaitu dari segi pembuatann RPP dan pelaksanaan pembelajaran di dalam kelas. Terjadi peningkatan derajat pedagogi disebabkan pembelajaran yang berpusat pada peserta didik, peningkatan kesadaran tentang kemungkinan dan keterbatasan kepercayaan mereka tentang sains pedagogi, dan munculnya pemahaman baru tentang konten kurikulum baru dan pedagogi sains. Pelaksanaan Lesson Study menggunakan sistem siklus, di mana setiap siklus dilaksanakan dalam 3 tahap yaitu (1) perencanaan (plan), (2) pelaksanaan (do), Refleksi (See).

\section{DAFTAR PUSTAKA}

Anggara, R., \& Chotimah, U. (2012). Penerapan Lesson Study Berbasis Musyawarah Guru Mata Pelajaran (MGMP) terhadap Peningkatan Kompetensi Profesional Guru PKn SMP Se-Kabupaten Ogan Ilir. Jurnal Forum Sosial.

Rizki, S. (2017). Efek Lesson Study Terhadap Peningkatan Kompetensi Pedagogik Calon Guru. AKSIOMA Journal of Mathematics Education, 3(1), 17-27. https://doi.org/10.24127/ajpm.v3i1.377

Rozak, A., \& Fauziah, E. (2013). Implementasi Lesson Study Sebagai Upaya Peningkatan Kompetensi Pedagogik Guru Bahasa Indonesia Di Smp Kabupaten Cirebon. Jurnal Pendidikan Bahasa Dan Sastra. https://doi.org/10.17509/bs_jpbsp.v13i1.754

Saito, E., Harun, I., Kuboki, I., \& Tachibana, H. (2006). Indonesian lesson study in practice: Case study of indonesian mathematics and science teacher education project. Journal of In-Service Education, 32(2), 171-184. https://doi.org/10.1080/13674580600650872

Samaranayake, G., Premadasa, K., Amarasinghe, R., \& Paneru, K. (2018). Teacher change through Lesson Study collaboration. International Journal for Lesson and Learning Studies, 7(4), 263-276. https://doi.org/10.1108/ijlls-12-2017-0055

Slameto. (2010). Belajar \& Faktor-Faktor yang Mempengaruhinya. Jakarta: Rineka Cipta.

Soto Gómez, E., Serván Núñez, M. J., Pérez Gómez, A. I., \& Peña Trapero, N. (2015). Lesson study and the development of 
1099 Pengaruh pelatihan lesson study terhadap kompetensi profesional guru di sekolah dasar - Elke Maisyarah, Fetri Yeni J

teacher's competences. International Journal for Lesson and Learning Studies, 4(3), 209223. https://doi.org/10.1108/ijlls-09-20140034

Tan, Y. S. M., \& Nashon, S. M. (2013). Promoting Teacher Learning Through Learning Study Discourse: The Case of Science Teachers in Singapore. Journal of Science Teacher Education, 24(5), 859-877. https://doi.org/10.1007/s10972-013-9340-5

Verhoef, N. C., \& Tall, D. O. (2011). Lesson Study: the Effect on Teachers' Professional Development. In 35th Conference of the International Group for the Psychology of Mathematics Education.

Vermunt, J. D., Vrikki, M., van Halem, N., Warwick, P., \& Mercer, N. (2019). The impact of Lesson Study professional development on the quality of teacher learning. Teaching and Teacher Education, 81, 61-73. https://doi.org/10.1016/j.tate.2019.02.009

Warwick, P., Vrikki, M., Vermunt, J. D., Mercer, N., \& van Halem, N. (2016). Connecting observations of student and teacher learning: an examination of dialogic processes in Lesson Study discussions in mathematics. ZDM - Mathematics Education, 48(4), 555569. https://doi.org/10.1007/s11858-0150750-z 